\title{
PENGEMBANGAN MEDIA E-BOOK INTERAKTIF PADA SUB MATERI PERMINTAAN, PENAWARAN, DAN HARGA KESEIMBANGAN
}

\author{
Rio Agatha Putra \\ Program Studi S1 Pendidikan Ekonomi, Fakultas Ekonomi, Universitas Negeri Surabaya \\ e-mail: rioputra1@mhs.unesa.ac.id \\ Retno Mustika Dewi \\ Program Studi S1 Pendidikan Ekonomi, Fakultas Ekonomi, Universitas Negeri Surabaya \\ e-mail: retnomustika@unesa.ac.id
}

\begin{abstract}
Abstrak
Media pembelajaran adalah segala sesuatu yang dapat digunakan untuk menyampaikan pesan atau informasi dalam proses belajar mengajar sehingga dapat merangsang perhatian dan minat peserta didik dalam belajar. Penelitian ini bertujuan untuk Mengetahui Pengembangan Media Pembelajaran E-book Interaktif Pada Mata Pelajaran Permintaan, Penawaran, dan Harga Keseimbangan. Objek dalam penelitian yaitu 20 peserta didik kelas X IIS SMA ISLAM AL-MIZAN SURABAYA. Jenis penelitian ini merupakan penelitian pengembangan dengan model pengembangan R\&D oleh Sugiono. Jenis data yang diolah yaitu data kuantitatif dan kualitatif. Berdasarkan hasil penelitian diperoleh data bahwa kelayakan media memperoleh persentase sebesar $86,4 \%$ dengan kategori sangat layak yang terdiri dari kelayakan ahli materi sebesar $91,3 \%$, ahli media sebesar $89,3 \%$, ahli bahasa sebesar $80 \%$, dan ahli grafis sebesar $85 \%$. Dari hasil belajar peserta didik diperoleh peningkatan yang dikategorikan tinggi, data uji pretest rata-rata peserta didik memperoleh nilai 45 sedangkan pada uji posttest rata-rata peserta didik memperoleh nilai 81. Sehingga dapat disimpulkan bahwa media E-Book Interaktif dapat meningkatkan hasil belajar peserta didik pada sub materi permintaan, penawaran, dan harga keseimbangan.
\end{abstract}

Kata Kunci: Media E-Book Interaktif, kelayakan media, hasil belajar.

\begin{abstract}
Learning media is anything that can be used to convey a message or information in the learning process so that it can stimulate the attention and interest of students in learning. This study aims to Know the Development of Interactive Learning Media Using E-book on the subject of demand, supply, and equilibrium prices. 20 students of class X IIS ISLAMIC AL-MIZAN SURABAYA are the objects of this study. This research uses the R\&D development model by Sugiono. The data used in this study is processed by the quantitative data and qualitative data method. Based on the results of the study, the feasibility of Interactive E-Book media shows a percentage of $86.4 \%$ with a very decent category consisting of material experts worth $91.3 \%$, media experts at $89.3 \%$, linguists at $80 \%$, and graphic experts at $85 \%$. From the student's learning outcome obtained in the research, it shows an increase that is categorized high. The average grade of students' pretest is 45, while the average grade in the posttest is 81. So, it can be concluded that the Interactive E-Book media can improve student learning outcomes on sub-material demand, supply, and price balance.
\end{abstract}

Keywords: Interactive E-Book Media, demand, supply, and balance results, media feasibility, learning outcomes.

\section{PENDAHULUAN}

Pendidikan adalah salah satu aspek dalam kehidupan yang paling utama di dunia, sehingga pendidikan menjadi acuan suatu negara dikatakan maju atau masih berkembang dilihat dari sumber daya manusianya.
Demikian dengan negara Indonesia yang saat ini menjadi salah satu warga dunia yang sedang mengalami perkembangan dalam berbagai aspek, terutama aspek pendidikan yang masih terus dikembangkan agar dapat bersaing dengan pendidikan di dunia. Pendidikan di Indonesia harus mengalami perubahan dalam hal 
kurikulum, media pembelajaran dan sarana prasarananya agar dapat bersaing dengan negara maju.

Di Indonesia dalam bidang pendidikan sudah mengalami perubahan dalam hal kurikulum yaitu dari KTSP menjadi K-13. Kurikulum terbaru menekankan pada proses pembelajaran pendekatan saintifik $5 \mathrm{M}$ (Pertama Mengamati, Kedua Menanya, Ketiga Mengumpulkan Informasi, Keempat Mengasosiasi, dan Kelima mengomunikasikan). Keberadaan media pembelajaran yang kreatif serta metode pembelajaran yang inovatif juga turut meningkatkan minat belajar atau rasa keingintahuan peserta didik atas materi yang diajarkan sehingga hal ini tentu akan meningkatkan kualitas pendidikan di Indonesia.

Mengacu pada hal diatas, pada hakikatnya proses belajar mengajar yang sudah diterapkan adalah proses komunikasi. Menurut Sadiman (2012) Media pembelajaran adalah sarana penyampaian informasi pada peserta didik, sehingga dapat dinyatakan media pembelajaran membantu memfasilitasi guru dalam proses belajar mengajar, serta bisa membantu meningkatkan prestasi belajar peserta didik. Menurut Arsyad (2014) Media pembelajaran selalu mengalami perubahan yang disesuaikan dengan kebutuhan pembelajaran. Setiap tahun media pembelajaran mengalami perubahan yang lebih inovatif untuk melengkapi kekurangan dari media yang sudah ada. Berdasarkan penggunaannya, media pembelajaran perlu pembaharuan atau penemuan media baru agar dapat menunjang pendidikan di era globalisasi. Salah satu dari begitu banyak yang dapat dikembangkan adalah media pembelajaran yang dapat menimbulkan interaksi berupa komunikasi seseorang melalui audio dan visualnya atau respon peserta didik (Trianto, 2011). Salah satu contohnya adalah video yang terdapat dalam media pembelajaran, dimana video tersebut dapat menimbulkan rasa penasaran dan keingintahuan peserta didik terhadap materi yang diajarkan.

SMA ISLAM AL MIZAN Surabaya merupakan SMA yang memiliki 2 jurusan yaitu MIA dan IIS, pada jurusan IIS peserta didik dibekali ilmu-ilmu sosial untuk menunjang kehidupan sosial mereka, dimana pada era globalisasi saat ini sangat perlu ilmu-ilmu sosial untuk mengikuti dan memilah perkembangan sosial dalam masyarakat serta dapat membantu peserta didik melanjutkan ke masa depan sesuai jenjang pendidikan yang lebih tinggi. Guru atau pendidik di SMA ISLAM AL MIZAN Surabaya sangat tertib dalam mempersiapkan kebutuhan untuk yang mendukung kegiatan belajar mengajar di kelas seperti yang dikutip dari Sudjana (2013) perangkat pembelajaran yaitu silabus, RPP, dan buku penunjang.
Salah satu guru atau pendidik mata pelajaran ekonomi juga mempersiapkan kebutuhan yang menyokong kegiatan belajar mengajar. Dalam silabus yang disusun, terdapat salah satu materi dalam mata pelajaran ekonomi kelas X SMA ISLAM AL MIZAN Surabaya yang berjudul permintaan, penawaran dan keseimbangan harga pasar. Materi tersebut memiliki kompetensi dasar menguraikan tentang permintaan, penawaran dan harga keseimbangan pasar diperlukan rasa ingin tahu, ketelitian dan perhitungan yang benar. Adanya media pembelajaran dalam memahami materi permintaan, penawaran dan harga keseimbangan pasar juga membantu tercapainya tujuan pembelajaran yang maksimal. Peserta didik pada materi tersebut dituntut dapat menghitung dengan tepat untuk memperoleh harga pasar.

Setelah mendapatkan hasil survei dengan wawancara guru ekonomi kelas X SMA ISLAM AL-MIZAN Surabaya mengatakan bahwa materi permintaan, penawaran dan harga keseimbangan pasar merupakan salah satu materi yang tergolong cukup sulit. Hal tersebut didasari adanya pemahaman rumus dan perhitungan yang tepat untuk memperoleh hasilnya serta ada faktor yang lain yang membuat materi tersebut sulit dipahami, yaitu pembelajaran dalam materi bukan hanya mengajarkan tentang konsep, melainkan juga meliputi ketelitian peserta didik dalam menghitung dengan tepat permintaan dan penawaran dengan demikian akan memperoleh harga keseimbangan pasar.

Hasil wawancara dengan Guru dan peserta didik didapatkan keterangan bahwa dalam proses pembelajaran materi permintaan, penawaran dan harga keseimbangan pasar sementara ini menggunakan metode konvensional berupa buku penunjang berupa buku ajar ekonomi namun peserta didik belum berperan aktif secara menyeluruh pada proses pembelajaran., hal ini menjadikan peserta didik menjadi pasif dan kurang aktif dalam materi permintaan, penawaran dan harga keseimbangan pasar. Sementara ini belum adanya Media Audio Visual Interaktif guna menunjang pembelajaran dan yang dapat mempermudah peserta didik dalam mempelajari sub materi. Berdasarkan keterangan dari guru saat wawancara, selama ini pendidik hanya menggunakan Lembar Kerja Siswa (LKS), buku ajar, dan powerpoint. Media-media tersebut memiliki kelemahan saat proses pembelajaran seperti ketika guru menggunakan LKS dan Buku Ajar, peserta didik merasa kesulitan untuk memahami karena di dalam LKS dan buku ajar hanya terdapat ringkasan materi dan latihan-latihan soal saja dalam hal ini peserta didik kesulitan untuk mengilustrasikannya atau memahaminya begitupun media Powerpoint, media ini sebenarnya media yang sudah cukup lengkap sebab dalam media ini bisa disisipkan video dan gambar agar siswa dapat mudah 
mengilustrasikannya atau memahaminya namun di SMA ISLAM AL-MIZAN Surabaya pemanfaatan media powerpoint masih kurang maksimal atau belum maksimal sebab powerpoint yang disajikan didominasi dengan tulisan ringkasan materi saja sehingga siswa mudah jenuh sehingga minat dalam proses atau kegiatan pembelajaran sangat kurang. Hal tersebut yang memicu ketidak maksimalan hasil belajar siswa.

Guru juga mengatakan bahwa pembelajaran pada materi permintaan, penawaran dan harga keseimbangan pasar kurang maksimal dan bahkan banyak peserta didik yang belum dapat mencapai nilai Kriteria Ketuntasan Minimum (KKM) dengan rincian di kelas X IIS, 1 Siswa mendapatkan nilai 30, 7 siswa mendapatkan nilai 40, 9 siswa mendapatkan nilai 50, 2 siswa mendapatkan nilai 60, dan 1 siswa mendapatkan nilai 70. Nilai diperoleh dari hasil ulangan harian sub materi permintaan, penawaran dan harga keseimbangan pasar. Oleh sebab itu peneliti mengambil materi permintaan, penawaran dan harga keseimbangan pasar untuk diteliti. Ketelitian dalam menghitung dan memahami rumus fungsi permintaan dan fungsi penawaran jadi hal utama untuk mencari hasil dari harga keseimbangan pasar. Selain itu dalam materi tersebut juga diajarkan tentang pengertian dan faktor yang mempengaruhi permintaan dan penawaran, kurva dan pergeseran kurva permintaan dan penawaran, hukum permintaan dan penawaran, serta elastisitas permintaan dan penawaran. Standar kompetensi yang diharapkan adalah pemahaman teori dan juga rumus serta perhitungan yang tepat. Dengan adanya standar kompetensi tersebut, peserta didik diharapkan dapat menghitung dengan tepat dan benar segala perhitungan yang diajarkan.

Media Interaktif dapat digunakan sebagai pendukung proses belajar mengajar dalam kompetensi perhitungan permintaan, penawaran, dan harga keseimbangan pasar sebab media ini dapat memacu interaksi peserta didik dan dapat digunakan berulang kali. Namun pada kenyataannya masih kurang sekali media interaktif yang sesuai dengan tujuan belajar pada materi permintaan, penawaran, dan harga keseimbangan pasar, pada penelitian dan pengembangan. Berawal dari permasalahan diatas muncul pernyataan media seperti apa yang mampu membangkitkan minat, menumbuhkan rasa percaya diri, dan memberikan kesempatan peserta didik melakukan evaluasi serta mencapai standar kompetensi. Mengacu dari hal tersebut maka dengan melihat serta memperhatikan konsep-konsep masalah yang sudah diketahui diperlukan adanya penyegaran media melalui media pembelajaran inovatif pada proses pembelajaran.

Menurut beberapa penelitian sebelumnya seperti penelitian dari Dewantara Arya Nugraha (2014) yang membahas pengembangan media berupa E-Book Interaktif hasil dari penelitian tersebut merujuk ke keberhasilan E-Book yang dapat menarik minat belajar dan hasil belajar yang memuaskan begitu juga hasil dari penelitian Naimatil Jannah (2017) dan Muhammad Alwan (2018) dimana mereka mendapatkan respon yang baik dari peserta didik, guru dan para ahli. Mereka mendapatkan tingkat keberhasilan diatas 85\% yang dilihat dari aspek respon siswa, tanggapan guru, dan validasi para ahli. Dalam penelitian ini memiliki perbedaan dalam hal materi yang berupa mata pelajaran ekonomi dan aplikasi media yg digunakan serta sajian di dalam E-book Interaktif berupa animasi, gambar dan video serta materi yang ringkas dan jelas sehingga dapat membuat focus peserta didik ke proses pembelajaran . Tujuan pembuatan media ini yaitu untuk memperbanyak media inovatif terutama di mata pelajaran ekonomi dan dapat meningkatkan kualitas pembelajaran mata pelajaran ekonomi.

Teknologi Informasi dan Komunikasi (TIK) dalam pengertiannya memiliki 2 aspek yaitu aspek teknologi sebagai memperoleh Informasi dan teknologi sebagai sarana komunikasi. Lee \& Osman(2011) Teknologi Informasi dan komunikasi adalah sebuah program yang dapat menunjang atau dapat dimanfaatkan untuk membuat media inovatif pendukung proses belajar mengajar yang dapat meningkatkan minat belajar peserta didik. Muller (2008) desain yang menarik dari sebuah media pembelajaran berpengaruh pada minat peserta didik agar pembelajaran lebih efektif.

Dari uraian diatas peneliti melakukan penelitian pengembangan media pembelajaran dengan media $E$ Book Interaktif, media ini diharapkan dapat memberikan hasil belajar peserta didik yang cukup meningkat dan media dapat layak digunakan oleh pendidik sehingga berpengaruh positif pada peningkatan pemahaman peserta didik dalam proses pembelajaran dan peningkatan hasil belajar peserta didik pada sub materi permintaan, penawaran, dan harga keseimbangan

\section{METODE}

Jenis metode yang digunakan dalam penelitian ini adalah metode R\&D (research and development) atau yang disebut sebagai penelitian dan pengembangan. Model ini berusaha untuk memecahkan masalah penelitian dengan cara menciptakan/ merevisi/memperbaiki suatu produk (Sugiyono, 2014). Produk yang dikembangkan dalam penelitian adalah media pembelajaran E-Book Interaktif yang digunakan pada salah satu materi di mata pelajaran ekonomi, yaitu permintaan, penawaran, dan harga keseimbangan pasar. 
Gambar 1 Tahap-tahap Penelitian

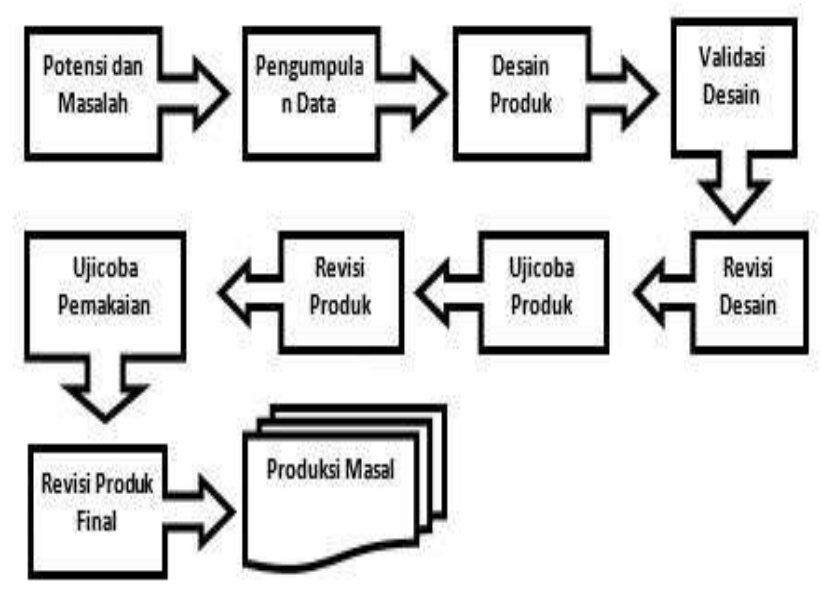

Sumber : (Sugiyono, 2014)

Berdasarkan aspek permasalahan serta jenis produk yang diproduksi, tahapan yang dilakukan penelitian tidak mencakup semuanya, melainkan hanya sampai tahap revisi produk. Hal ini dilakukan karena pada penelitian ini berusaha untuk memecahkan masalah di suatu lokasi saja, yaitu di Kelas X SMA AL MIZAN Surabaya, khususnya pada mata pelajaran Ekonomi.

Sumber data yang digunakan adalah peserta didik kelas X yang berjumlah 20 siswa serta guru ekonomi di SMA AL MIZAN Surabaya dan Subjek dalam penelitian ini adalah media $E$-Book Interaktif yang dikembangkan.

Prosedur penelitiannya yaitu mencari potensi dan masalah, Potensi adalah "segala sesuatu yang bila didayagunakan akan memiliki nilai tambah" (Sugiono, 2014). Dalam hal ini kurikulum pembelajaran ekonomi sub materi permintaan, penawaran, dan harga keseimbangan pasar menuntut adanya perkembangan IPTEK. Perkembangan IPTEK merupakan sebuah potensi yang berguna untuk membuat inovasi baru, khususnya dalam sistem kegiatan belajar mengajar. Banyak hal yang dapat dilakukan adalah dengan terciptanya media pembelajaran yang inovatif. Pengaplikasian media pembelajaran tersebut salah satunya dalam pembelajaran ekonomi di mana pembelajaran tidak hanya cukup melalui penyampaian dengan variasi metode pembelajaran akan tetapi juga membutuhkan variasi terbaru dalam media pembelajaran yang menarik dan menyenangkan

Berdasarkan observasi yang dilakukan di SMA ISLAM AL MIZAN Surabaya, fasilitas dari segi teknologi yang ada dan cukup memadai, semacam LCD, dan Lab. multimedia. Keberadaan Lab. multimedia di sekolah menjadi sebuah potensi yang dapat digunakan atau dimanfaatkan dalam proses atau kegiatan pembelajaran, akan tetapi fasilitas tersebut belum sepenuhnya dimanfaatkan dengan tepat secara maksimal untuk mendukung terlaksananya pembelajaran ekonomi.
Media pembelajaran yang menggunakan/berbasis teknologi masih sangat kurang sehingga beberapa kali menjadi penghambat dalam kegiatan belajar mengajar. Media pembelajaran berbasis teknologi yang digunakan guru dalam mengajar yaitu slide Microsoft Power Point dan video tutorial youtube, sehingga menjadikan proses pembelajaran kurang membuat peserta didik tertarik untuk mengikuti pembelajaran dan peserta didik cepat merasa bosan (hasil wawancara dengan 2 orang siswa), terlihat dari adanya siswa yang mengobrol sendiri, pada peserta didik yang terlihat cepat lelah pada saat proses pembelajaran berjalan. Selanjutnya masuk ke tahap kedua mengumpulkan informasi dimana sumber informasi didapatkan melalui survei di lapangan dengan menggunakan teknik wawancara dan menyebarkan angket yang berisi tanggapan tentang media pembelajaran pada sub materi permintaan, penawaran dan harga keseimbanagan pasar. Selanjutnya tahap ketiga yaitu bentuk desain produk berupa E-Book Interaktif yang dipilih sebagai media yang akan dipakai dalam pembelajaran ekonomi sub materi permintaan, penawaran dan harga keseimbangan.

Langkah selanjutnya yaitu Validasi, di mana pada tahap ini akan dilakukan penilaian produk kepada para pakar atau ahli yang berpengalaman sehingga produk dapat diketahui kelebihan dan kekurangannya. Menurut Sugiono (2014) validasi desain adalah suatu proses penilaian terhadap rancangan produk, dalam hal ini media pembelajaran apakah secara rasional lebih efektif atau lebih baik dari yang lama. Dalam penelitian ini, penilaian produk terbagi ke dalam beberapa jenis, diantaranya validator ahli media, validator ahli materi, validator ahli grafis, dan validator ahli bahasa. Adapun kriteria penilaian produk tercantum pada tabel di bawah ini.

Tabel 1 Interpretasikan presentase

\begin{tabular}{ll}
\hline Kategori & Persentase \\
\hline Sangat Tidak Valid & $0 \%-20 \%$ \\
\hline Tidak valid & $21 \%-40 \%$ \\
\hline Cukup valid & $41 \%-60 \%$ \\
\hline Valid & $61 \%-80 \%$ \\
\hline Sangat valid & $81 \%-100 \%$ \\
\hline
\end{tabular}

Sumber : (Riduwan, 2012)

Setelah keempat validator memberikan tanggapan dan penilaian terhadap media yang dikembangkan langkah selanjutnya adalah melakukan perbaikan/revisi yang didasarkan pada hasil kegiatan validasi. Setelah melalui tahap revisi, produk akan diuji coba. Dalam kegiatan uji coba produk pembelajaran,dapat dilakukan baik melalui perseorangan/individu, melalui kelompok kecil, atau juga melalui tes lapangan dalam proses pembelajaran yang 
sesungguhnya. Pada penelitian ini kegiatan uji coba dilakukan pada siswa kelas SMA AL MIZAN Surabaya yang berjumlah 20 orang. Pada tahap ini media interaktif digunakan akan digunakan oleh peserta didik dengan diberikan keterangan tata cara penggunaan sehingga peserta didik dapat mengoperasikan dengan mudah dan diharapkan dapat memperoleh penilaian terhadap media interaktif yang telah dikembangkan.

Sasaran uji coba, yaitu peserta didik dilatarbelakangi dengan beragam karakteristik seperti tingkat kepandaian, latar belakang siswa, kemajuan belajar dan faktor-faktor lainnya. Pada tahap ini, peneliti akan menemukan/mengetahui tingkat kemampuan siswa dalam memahami media, kemudahan dalam mengoperasikan, dan tingkat ketertarikan media pembelajaran.

Penelitian ini memiliki instrumen yang disusun oleh peneliti berupa lembar validasi. Lembar validasi diberikan pada keempat ahli yang telah ditentukan guna mengetahui kualitas produk yang dikembangkan. Instrumen lain yang digunakan yaitu lembar pre test, post test, dan angket respon yang diberikan kepada peserta didik.

Penganalisisan data yang dilakukan berupa teknik deskriptif. Teknik tersebut terbagi lagi ke dalam dua jenis, yaitu analisis deskriptif kualitatif dan deskriptif presentase.

a. Hasil analisis dari masing-masing ahli validasi media E-Book Interaktif berikut dilakukan guna memperoleh hasil validitas media E-Book Interaktif. Hasil validitas diperoleh dari rata-rata nilai yang diberi oleh ahli validasi media, ahli validasi materi, ahli validasi bahasa, dan ahli validasi grafis dengan cara memberikan rentang nilai $1-5$ (1=sangat tidak setuju, 2=tidak setuju, 3=cukup, 4=setuju, 5=sangat setuju) pada setiap aspeknya. Skor dari validasi yang telah diperoleh sebagai tolak ukur media.

Persentase Kevalidan (\%) = $\sum$ skor yang diperoleh : Sskor maksimal $\frac{\sum \text { skoryangdiperoleh }}{\sum \text { skormaksimal }} \times 100 \%$

Media akan dinyatakan valid apabila persentasenya mencapai $\geq 61 \%$.

b. Hasil analisis yang digunakan dalam pemerolehan hasil belajar siswa terbagi ke dalam dua kategori. Kategori pertama yaitu ketuntasan individu yang didasarkan pada nilai ketuntasan minimal (KKM) di mana untuk mata pelajaran ekonomi nilai ketuntasan minimal yang ditetapkan oleh sekolah adalah 70 . Berdasarkan hal tersebut, peserta didik dikatakan mendapatkan nilai yang baik/tuntas jika mampu mendapatkan nilai diatas 70. Jika masih di bawah 70, maka dikatakan belum tuntas. Sedangkan kategori lainnya didasarkan pada ketuntasan klasikal yang dilihat dari ketuntasan keseluruhan peserta didik. Rumus menurut Riduwan (2012) untuk memperoleh persentase ketuntasan klasikal yaitu :

$\mathrm{P}$

$=\frac{\sum \text { jumlah siswa yang mendapat nilai } \geq 70}{\sum \text { siswa yang mengikuti tes }} \times 100 \%$

Keterangan :

$\mathrm{P}=$ Persentase Ketuntasan Klasikal

Ketuntasan klasikal dikatakan berhasil bila mencapai $\geq 85 \%$ dari jumlah total peserta didik

c. Analisis ini digunakan untuk memperoleh hasil keefektifan media E-Book Interaktif yang dikembangkan. Lembar angket yang akan diberikan kepada peserta didik berisi beberapa butir pertanyaan dengan tipe pertanyaan yang hanya membutuhkan jawaban "Ya" atau Tidak" sesuai dengan skala Guttman

Hasil angket respon peserta didik yang menjawab positif atau "Ya" dapat dihitung dengan rumus menurut Riduwan (2012) sebagai berikut :

$\begin{array}{lll}\text { Respon positif } & (\%) & = \\ \frac{\sum \text { siswayangmenjawab “ } Y a^{\prime}}{\sum \text { seluruhsiswa }} & \frac{\sum \text { siswayangmenjawab “ } Y a^{\prime}}{\sum \text { seluruhsiswa }} & \mathrm{X} \\ 100 \% & \end{array}$

Hasil dari Perhitungan menggunakan rumus diatas akan diinterpretasikan dalam bentuk skala Likert seperti tabel berikut :

Tabel 2 Interpretasikan presentasi

\begin{tabular}{|l|l|}
\hline \multicolumn{1}{|c|}{ Kategori } & \multicolumn{1}{c|}{ Persentase } \\
\hline Sangat Tidak Valid & $0 \%-20 \%$ \\
\hline Tidak Valid & $21 \%-40 \%$ \\
\hline Cukup Valid & $41 \%-60 \%$ \\
\hline Valid & $61 \%-80 \%$ \\
\hline Sangat Valid & $81 \%-100 \%$ \\
\hline
\end{tabular}

Sumber : (Riduwan, 2012)

Hasil analisis respon peserta didik dapat dikatakan valid bila mana presentase perhitungan respon positif mencapai $\geq 61 \%$.

\section{HASIL DAN PEMBAHASAN}

Tahap pencarian potensi dan masalah diperoleh dari hasil wawancara peserta didik dan guru disekolah. Sekaligus pengumpulan data mengenai hasil belajar peserta didik dan pengembangan belajar peserta didik saat mapel ekonomi. Setelah itu pembuatan media $E$ Book Interaktif yang sesuai untuk mengatasi masalah 
peserta didik dan guru. Saat media E-Book Interaktifnya selesai dibuat media langsung divalidasi oleh ahli media, ahli materi, ahli Bahasa dan ahli grafik. Terdapat beberapa media yang direvisi sebelum di uji cobakan ke peserta didik termasuk revisi dalam Bahasa dan beberapa penataan urutan media. Setelah revisi selesai dan para ahli memberikan penilaian yang layak maka media langsung diuji cobakan kepada peserta didik, dalam ujicoba media mendapatkan respon yang baik dari peserta didik dan guru mata pelajaran ekonomi, saat dilakukan uji coba ke peserta didik antusias peserta didik sangat bagus dan juga hasil belajarnya juga memperoleh hasil diatas KKM. Dalam penelitian ini tidak sampai mencapai produksi massal sebab penelitian ini bertujuan untuk menyelesaikan masalah dalam ruang lingkup SMA Islam Al-Mizan Surabaya.

Analisis hasil kelayakan E-Book Interaktif yang diperoleh dari ahli materi, berupa persentase dengan rincian yang pertama pada variabel Kualitas isi dan tujuan meliputi ketepatan, keseimbangan, minat dan perhatian memperoleh total rata-rata $84 \%$, selanjutnya yang ke dua variabel kualitas instruksional meliputi kualitas motivasi, dampak bagi peserta didik, dan dampak bagi guru memperoleh total rata-rata $100 \%$, terakhir yang ke ketiga variabel kualitas teknis meliputi keterbacaan memperoleh total rata-rata $90 \%$. Sehingga mengacu dari data prosentase tersebut menurut ahli materi tentang $E$ Book Interaktif sangat layak digunakan menjadi media pembelajaran.

Analisis hasil kelayakan E-Book Interaktif yang diperoleh dari ahli media, berupa persentase dengan rincian yang pertama pada variabel Kualitas isi dan tujuan meliputi ketepatan, kepentingan, dan keseimbangan memperoleh total rata-rata $90 \%$, selanjutnya yang ke dua variabel kualitas instruksional meliputi memberikan kesempatan belajar memperoleh total rata-rata $90 \%$, terakhir yang ke ketiga variabel kualitas teknis, yaitu meliputi memberikan bantuan belajar, kualitas untuk memotivasi, keterbacaan, kualitas tampilan, kualitas pengolahan memperoleh total rata-rata $88 \%$. Sehingga mengacu dari data prosentase tersebut menurut ahli media tentang E-Book Interaktif sangat layak digunakan menjadi media pembelajaran.

Analisis hasil kelayakan E-Book Interaktif yang diperoleh dari ahli bahasa, berupa persentase dengan rincian yang pertama pada variabel Kualitas isi dan tujuan meliputi komponen kesesuaian dengan tingkat perkembangan pendidik memperoleh total rata-rata $80 \%$, selanjutnya yang ke dua variabel kualitas teknis meliputi bahasa yang digunakan lugas, bahasa yang digunakan komunikatif, dan penggunaan istilah mudah dipahami memperoleh total rata-rata $80 \%$. Sehingga mengacu dari data prosentase tersebut menurut ahli bahasa tentang $E$ -
Book Interaktif layak digunakan menjadi media pembelajaran.

Analisis hasil kelayakan E-Book Interaktif yang diperoleh dari ahli grafis, berupa persentase dengan rincian variabel keseimbangan, bentuk, dan warna memperoleh total rata-rata $85 \%$. Sehingga mengacu dari data prosentase tersebut menurut ahli grafis tentang $E$ Book Interaktif sangat layak digunakan menjadi media pembelajaran.

Analisis hasil belajar peserta didik berupa hasil pretest dan posttest, pada pretest sebelum peserta didik mengenal media pembelajaran E-Book Interaktif pada sub materi permintaan, penawaran, dan harga keseimbangan diperoleh suatu data dimana hanya 1 peserta didik yang dapat mencapai ketuntasan, 19 peserta lainnya tidak mencapai ketuntasan dengan KKM > 70, sehingga bila di presentase hanya 5\% dari $100 \%$ yang berhasil mencapai ketuntasan. Setelah peserta didik mengenal E-Book Interaktif pada sub materi permintaan, penawaran, dan harga keseimbangan dan dilakukan posttest tersebut diperoleh suatu data dimana semua peserta didik atau jumlah totall 20 peserta didik dapat mencapai ketuntasan dengan nilai diatas KKM > 70 , sehingga data persentase yang diperoleh yaitu $100 \%$ untuk ketuntasannya.

Analisis hasil respon peserta didik diperoleh presentase mencapai $96,667 \%$ sehingga dapat disimpulkan bahwa Media E-Book Interaktif pada sub materi permintaan, penawaran, dan harga keseimbangan untuk kelas $X$ IIS di SMA ISLAM AL-MIZAN memperoleh respon positif dari peserta didik

\section{SIMPULAN DAN SARAN}

Dari penjabaran yang dilakukan, dapat disimpulkan bahwa hasil validasi para ahli terhadap media E-Book Interaktif sangat layak digunakan untuk media pembelajaran dan media E-Book Interaktif pada sub materi permintaan, penawaran, dan harga keseimbangan untuk kelas $\mathrm{X}$ IIS di SMA ISLAM AL-MIZAN dikategorikan media pembelajaran yang "Sangat Layak" digunakan. Hasil belajar peserta didik meningkat ketika peserta didik telah mempelajari materi dari media E-Book Interaktif, serta respon yang baik dari peserta didik mengenai media E-Book Interaktif pada sub materi permintaan, penawaran, dan harga keseimbangan sesuai dengan jurnal yang dibahas oleh (Atmawarni, 2011) dan jurnal kutipan (Rini, Mulyono, \& Yusran, 2017).

Media E-Book Interaktif mendapatkan respon positif sehingga diharapkan dapat diterapkan untuk mendukung proses pembelajaran pada mata pelajaran ekonomi guna memudahkan peserta didik dalam memahami materi dan membantu guru dalam mencapai tujuan pembelajaran. Guru disarankan dapat mengembangkan media E-Book 
Interaktif ini dengan memperluas cakupan materi. Penelitian ini diharapkan dapat dikembangkan lebih lanjut untuk meningkatkan minat dan hasil belajar peserta didik.

\section{DAFTAR PUSTAKA}

Arsyad, A. (2014). Media Pembelajaran.

Alwan,Muhammad. (2018). PENGEMBANGAN MEDIA E-BOOK 3D BERBASIS MOBILE LEARNING UNTUK MATA PELAJARAN GEOGRAFI SMA GUNA MENDUKUNG PEMBELAJARAN JARAK JAUH.

Atmawarni. (2011). PENGGUNAAN MULTIMEDIA INTERAKTIF GUNA MENCIPTAKAN PEMBELAJARAN YANG INOVATIF DI SEKOLAH, 4(April 2011), 20-27.

Dewantara,Arya Nugraha. (2014). PENGEMBANGAN MEDIA E-BOOK INTERAKTIF BILINGUAL PADA MATERI POKOK KALOR UNTUK SMA KELAS X

Lee, T. T., \& Osman, K. (2011). EFFECTIVENESS OF INTERACTIVE MULTIMEDIA MODULE WITH PEDAGOGICAL AGENT ( IMMPA ) IN THE LEARNING OF ELECTROCHEMISTRY : A PRELIMINARY INVESTIGATION, 12(2), 1-24.

Naimatil,Jannah. (2017). PENGEMBANGAN E-BOOK INTERAKTIF BERBASIS FENOMENA KEHIDUPAN SEHARI-HARI TENTANG PEMISAHAN CAMPURAN.

Muller, D. A. (2008). Designing Effective Multimedia for Physics Education.

Riduwan. (2012). Rumus dan Dalam Aplikasi Statistika.

Rini, S., Mulyono, H., \& Yusran. (2017). PENGEMBANGAN MEDIA PEMBELAJARAN INTERAKTIF $E$-BOOK UNTUK MATA PELAJARAN SIMULASI KOMUNIKASI DIGITAL DI SMKN N 6 KOTA PADANG.

Sadiman, A. S. (2012). Media Pendidikan (pengertian, pengembangan, dan pemanfaatan).

Sudjana, N. (2013). Dasar Dasar Proses Belajar Mengajar. Bandung: Sinar baru Algensindo.

Sugiono. (2014). Metode Penelitian.

Trianto. (2011). Model Pembelajaran Terpadu. 